(RESEARCH ARTICLE)

\title{
Physicochemical and sensory properties of tree tomato (Cyphomandra betacea (Cav.) Sendtner) drink
}

Njoya Moyouwou Amadou*, Nain Caroline Waingeh, Nde Sylvanus Che, Mahbou Peter Yunenyui and Imele Helène

Food Technology and Post-Harvest Laboratory, IRAD-Bambui; P.O. Box 51 Bamenda, Cameroon.

Publication history: Received on 17 March 2020; revised on 29 April 2020; accepted on 30 April 2020

Article DOI: https://doi.org/10.30574/wjarr.2020.6.2.0068

\begin{abstract}
The aim of the present study was to investigate on the physicochemical properties of the tree tomato drink, its sensory properties and shelf-life. Three tree tomato drink treatments were obtained with three levels of dilution (w/v) of tree tomato paste: $1: 1 ; 1: 2$ and $1: 3$ respectively for treatments $\mathrm{T}_{1}, \mathrm{~T}_{2}$ and $\mathrm{T}_{3}$. Physicochemical properties of drink treatments determined at the day of production (day 0 ) included $\mathrm{pH}$, titratable acidity, dry matter content, sugar content and ash content. The $\mathrm{pH}$, titratable acidity and sugar content were also evaluated during 12 weeks (84 days) of storage at room temperature under unlight at 1 week's intervals from day 0 . The sensory attributes evaluated were colour, odour, taste, texture and overall acceptability. From the study, treatment $\mathrm{T}_{1}$ had significantly $(\mathrm{P} \leq 0.05)$ the highest titratable acidity, dry matter content, sugar content and ash content while the $\mathrm{pH}$ of tree tomato drink increased with dilution. The $\mathrm{pH}$, titratable acidity and sugar content of all the treatments remained unchanged $(\mathrm{P}>0.05)$ during the storage period. The colour of treatment $\mathrm{T}_{3}$ and the taste of treatment $\mathrm{T}_{1}$ were lowly $(\mathrm{P} \leq 0.05)$ appreciated across all the treatments. However, treatment $\mathrm{T}_{2}$ was highly $(\mathrm{P} \leq 0.05)$ preferred in terms of odour, consistency and overall acceptability. After storage, colour, odour and taste of all the treatments were similar $(\mathrm{P}>0.05)$ while the consistency and overall acceptability of Treatment $\mathrm{T}_{2}$ were more preferable $(\mathrm{P} \leq 0.05)$ than those of treatment $\mathrm{T}_{1}$. Treatment $\mathrm{T}_{2}$ could be recommended for manufacturing and the drink might be stored for 12 weeks and above.
\end{abstract}

Keywords: Tree tomato; Drink; Physicochemical and sensory properties; Storage

\section{Introduction}

Tree tomato or tamarillo (Cyphomandra betacea (Cav.) Sendtner), neglected andean crop [1], belongs to the solanaceae family such as tomato, eggplant, tamatillo, ground cherry and chilli pepper. It is a shrub native from South America in subtropical Andes. The plant could be native from Peru and Brazil [2] or Bolivia according to its area of origin [3, 4]. In fact, $S$. betaceum (Cyphomandra betacea) is closely related to $S$. unilobum, $S$. roseum, and in particular to $S$. maternum, all of which are found in Bolivia in wild status [4-7]. It is mostly cultivated in Brazil, Argentina, Mexico, Panama, Spain, India, South Africa and Unites States of America and the fruits have become an important marketable crop in these countries as well as in Colombia and New Zealand. The crop have been developed in Colombia, Ecuador and New Zealand where the production and exportation have increased in the last decades [5, 8-10]. The fruits naturally acidic are highly appreciated for their organoleptic and nutritional properties. They can be consumed in juice and as fresh fruit; cooked as ingredient for different dishes (stew and sauces) and dessert; prepared as chutney and pickles; eaten directly as salad or part of salads.

In Cameroon, tree tomato is an indigenous fruit which grows especially in the North-West region [11]. Many years ago, the fruit was consumed fresh and as juice. Culinary, it was also used as tomato substitute in sauce (stew) and soup preparation, salt or cube during preparation of yellow soup for Achu (traditional dish in Cameroon) consumption. At present, the tree is desperate and many farmers abandoned its cultivation rendering it uncommon and less marketable.

* Corresponding author: Njoya Moyouwou Amadou e-mail: njoyaamadou5@gmail.com; Tel: 00(237)677860978 
While it is a promising crop for some regions characterised by a Mediterranean climate [12] such as the West and NorthWest region of Cameroon. On the other hand, tree tomato presents many nutritionally and health advantages which are benefit for human body.

Tree tomato fruit represents a source of provitamin A, vitamins C, E and $B_{2}$ and iron [13-16]. It possesses levels of nitrogen and free amino acids higher than those of most fruits except avocados and bananas and, its potassium and phosphorus contents are also high among fruits, which are normally poor sources of these elements [17]. It is also rich in fibres which contribute to lower the blood cholesterol level and facilitate digestion. Mature tree tomato fruit juice is traditionally used for the treatment of tonsillitis, high cholesterol and stomach pain [18]. It also contains a significant amount of bioactive compounds such as anthonyacins, phenolic compounds and carotenoïds [19] which are endowed with antioxidant properties. The fruit is potentially a functional food ingredient and its use in human diets might provide protection and help to reduce oxidative damages in different vital organs [20] and, the presence of carotenoids and anthocyanins indicates biological, therapeutic and preventive properties [21]. It also presumed therapeutic value to the liver [17]. Due to its acidity, consumption of tree tomato fruits could help the body to lower the body weight, the blood cholesterol and sugar level; prevents high blood pressure level and contributes to maintain the heart in good health.

In order to valorise the indigenous fruits for their maintaining and cultivation, and also to increase the shelf-life of the fruits, the aim of the present study was to investigate on the physicochemical properties of the tree tomato drink, its sensory appreciation and shelf-life through evaluation of $\mathrm{pH}$, sugar content and titratable acidy change during storage.

\section{Material and methods}

\subsection{Preparation of tree tomato puree}

Raw tree tomato fruits (mixture of yellow, red-purple and hybrid from the red-purple and yellow varieties) purchased from the local market in Bamenda, North-West region of Cameroon, were brought to the Food Technology and PostHarvest laboratory of IRAD Bambui. After sorting, they were washed with potable water and boiled for few minutes. After cooling, the peelings were removed and the pulp mixed to become homogenous. The physicochemical composition of the pulp or puree is given below in table 1 .

Table 1 Physicochemical composition of tree tomato puree

\begin{tabular}{|c|c|c|c|c|c|}
\hline & $\begin{array}{l}\text { Titratable acidity } \\
\text { (\% Citric acid) }\end{array}$ & $\mathbf{p H}$ & $\begin{array}{l}\text { Dry } \\
(\%)\end{array}$ & Ash (\%) & Sugar $\left({ }^{\circ}\right.$ Brix $)$ \\
\hline Tree tamato puree & $0.67 \pm 0.50$ & $4.08 \pm 0.14$ & $9.64 \pm 0.84$ & $0.95 \pm 0.17$ & $8.7 \pm 1.03$ \\
\hline
\end{tabular}

\subsection{Preparation of tree tomato drink}

Tree tomato drink was obtained by addition of potable water to the puree obtained and the mixture sieved doubly using a muslin cloth. The drink was then successively pasteurised $\left(75^{\circ} \mathrm{C} / 3-5 \mathrm{~s}\right.$ ) in presence of $10 \%$ (w/v) of sugar added at $60-65{ }^{\circ} \mathrm{C}$, packaged in sterilised glass bottles, sterilised by boiling (20 min), cooled at room temperature and stored in the same conditions and out of sun light.

According to the quantity of water added to the puree, three treatments were obtained:

- $\quad$ Treatment $\mathrm{T}_{1}: 1 \mathrm{~kg}$ of puree and $1 \mathrm{l}$ of water (dilution 1:1 (w/v))

- Treatment $\mathrm{T}_{2}: 1 \mathrm{~kg}$ of puree and $2 \mathrm{l}$ of water (dilution 1:2(w/v))

- Treatment $\mathrm{T}_{3}: 1 \mathrm{~kg}$ of puree and $3 \mathrm{l}$ of water (dilution 1:3 (w/v))

The samples obtained were submitted to physicochemical analysis and sensory evaluation.

\subsection{Physicochemical analysis}

The physicochemical properties analysed were:

- $\quad$ Titratable acidity by titration with Sodium Hydroxide $\left(\mathrm{N}_{\mathrm{a}} \mathrm{OH}\right) 0.1 \mathrm{M}$ with phenolphthalein $0.5 \%$ as indicator [22]. The titratable acidity (TA) was expressed as citric acid content (\% citric acid) using a formula: 
- $\mathrm{pH}$ using a manual $\mathrm{pH}-\mathrm{meter}$

$\mathrm{TA}(\%$ citric acid $)=(\mathrm{V} \mathrm{N} \mathrm{aOH}(\mathrm{ml}) \times 0.1 \times 0.065 \times 100) /$ Volume of sample $(\mathrm{ml})$

- Sugar content ( ${ }^{\circ}$ Brix) with an eclipse handled refractometer

- Dry matter as described by AOAC [22].

- Ash content according to AOAC [22].

$\mathrm{pH}$, titratable acidity and sugar content were also determined during 84 days (12 weeks) of storage at regular intervals of 02 weeks from the day of production (manufacturing) or day 0.

\subsection{Sensory evaluation}

Sensory evaluation of all tree tomato drink treatments was carried out using a five-point hedonic scale with the following as categories: Excellent=5; Very Good=4; Good=3; Fair=2 and Poor=1. Colour (appearance), flavour (aroma), texture, taste and overall acceptability of tree tomato drink treatments were evaluated by an untrained panel of 30 persons between 20 and 60 years old who were made of researchers, technicians and students on internship of the centre of IRAD-Bambui. It was done on the day of manufacturing (day 0 ) and at the end of the storage period (84 days or 12 weeks).

\subsection{Statistical analysis}

Data obtained were expressed as Mean \pm SD and subjected to the Analysis of variance (ANOVA) using the Statgraphics Plus, version 5.0 statistical package. The means obtained were separated using the Fischer Test (LSD) at 95\% confidence level.

\section{Results and discussion}

\subsection{Physicochemical properties of tree tomato drink}

The physicochemical properties of tree tomato drink treatments are presented in table 2 . The $\mathrm{pH}$ values obtained were not significantly different $(P>0.05)$ between treatments $T_{1}$ and $T_{2}$ and, treatments $T_{2}$ and $T_{3}$. However, Treatment $T_{3}$ showed the highest $\mathrm{pH}$ value which was significantly different $(\mathrm{P} \leq 0.05)$ to that of treatment $\mathrm{T}_{1}$. Thus, the increase of the dilution led to the increase of $\mathrm{pH}$ due to the fact that, the $\mathrm{pH}$ value of the drinking (potable) water is almost neutral (slightly acidic) and at low level, it might not significantly affect the $\mathrm{pH}$ of the solution. Treatment $\mathrm{T}_{1}$ showed the highest value $(\mathrm{P} \leq 0.05)$ of titratable acidity; dry matter, sugar and ash contents. Moreover, the increase of the level of dilution involved the decrease of those parameters. This result was expected by the dilution of components and also considering the fact that potable water doesn't have or has very low (traces) of titratable acidity or citric acid content; dry matter, sugar and ash contents.

Table 2 Physicochemical properties of tree tomato drink treatments

\begin{tabular}{llll}
\hline & \multicolumn{3}{l}{ Treatments } \\
\hline Parameters & $\mathbf{T}_{\mathbf{1}}$ & $\mathbf{T}_{\mathbf{2}}$ & $\mathbf{T}_{3}$ \\
\hline $\mathrm{pH}$ & $4.28 \pm 0.10 \mathrm{~b}$ & $4.44 \pm 0.15 \mathrm{ab}$ & $4.56 \pm 0.16 \mathrm{a}$ \\
Titratable acidity $(\%$ citric acid) & $0.60 \pm 0.02 \mathrm{a}$ & $0.41 \pm 0.02 \mathrm{~b}$ & $0.30 \pm 0.02 \mathrm{c}$ \\
Dry matter $(\%)$ & $14.54 \pm 2.28 \mathrm{a}$ & $12.06 \pm 0.83 \mathrm{~b}$ & $11.38 \pm 1.11 \mathrm{c}$ \\
Sugar content $\left({ }^{\circ} \mathrm{Brix}\right)$ & $14.2 \pm 2.01 \mathrm{a}$ & $11.6 \pm 1.02 \mathrm{~b}$ & $10.6 \pm 1.51 \mathrm{~b}$ \\
Ash content $(\%)$ & $0.42 \pm 0.05 \mathrm{a}$ & $0.28 \pm 0.03 \mathrm{~b}$ & $0.16 \pm 0.03 \mathrm{c}$
\end{tabular}

$(\mathrm{a}, \mathrm{b}, \mathrm{c})$ : The values with the same letter in the same row are not significant different (P>0.05) $\mathrm{T}_{1}: 1 \mathrm{~kg}$ of tree tomato puree and $1 \mathrm{l}$ of water (dilution 1:1 (w/v)); $\mathrm{T}_{2}: 1 \mathrm{~kg}$ of tree tomato puree and $2 \mathrm{l}$ of water (dilution 1:2 (w/v)); T3: $1 \mathrm{~kg}$ of tree tomato puree and $3 \mathrm{l}$ of water (dilution 1:3 (w/v)).

\section{2. $\mathrm{pH}$, titratable acidity and sugar content change in tree tomato drink during 84 days of storage}

The figure 1 below shows the $\mathrm{pH}$ change of tree tomato drink treatments during 84 days (12 weeks) of storage. $\mathrm{pH}$ values of each treatment were not significantly $(\mathrm{P}>0.05)$ affected with increasing of storage duration. This results is in accordance with that of El-Dengawy et al. [23] who did not observed significant change on $\mathrm{pH}$ during 18 Months storage of tomato juice. The tomato juice was sterilised at $100{ }^{\circ} \mathrm{C}$ during $30 \mathrm{~min}$ and $\mathrm{pH}$ values varied between 4.5 and 4.2. In fact, during heat treatment (boiling, pasteurisation or sterilisation), there should be enzyme denaturation and microorganisms' destruction and subsequently low metabolic activity leading to acidic or basic components production, 
which could significantly induce $\mathrm{pH}$ change. Also, the $\mathrm{pH}$ values of drink treatments varied from 4.28 to 4.62 during storage and, higher acidity levels $(\mathrm{pH}<4.6)$ are often unfavourable to the survival of microorganisms [24]. Tilahum et al. [25] obtained rather an increase of $\mathrm{pH}$ values of tomato juice (1 ml juice $/ 19 \mathrm{ml}$ distilled water) with increasing storage duration and could be explained by the fact that the extracted juice was not pasteurised or treated. However, during storage, $\mathrm{pH}$ of tomato increase [26-28] as result of consumption of various organics acid [29]. According to Pinzón-Gómez et al. [30], fruits (tamarillo) which were not immersed in calcium chloride showed lower pH values during storage compared to the fruits that received applications of calcium, and may be correlated to the inhibition of the catalytic activity of enzymes in presence of calcium [31].

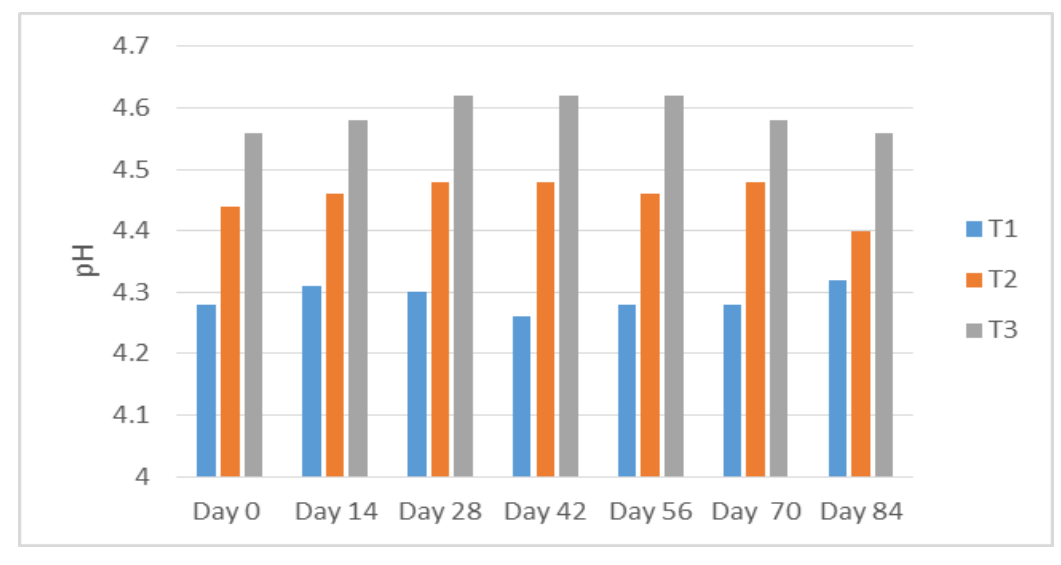

\section{$\mathrm{T}_{1}: 1 \mathrm{~kg}$ of tree tom ato puree and 11} of water (dilution 1:1 (WN))

$\mathrm{T}_{2}: 1 \mathrm{~kg}$ of tree tom ato puree and 21 of water (dilution 1:2(WW))

$\mathrm{T}_{3}: 1 \mathrm{~kg}$ of tree tom ato puree and 31 of water (dilution 1:3(WW))

Figure 1 Histogram of pH change of tree tomato drink during 84 days (12 weeks) of storage

During the storage period, treatment $\mathrm{T}_{3}$ had the highest $\mathrm{pH}$ value and this value significantly different $(\mathrm{P} \leq 0.05)$ with that of treatment $\mathrm{T}_{1}$. This result should be in relation with the high $\mathrm{pH}$ value of treatment $\mathrm{T}_{3}$ on the manufacturing day (beginning of storage) considering the low microbial activity and the low enzymes' activity due to low $\mathrm{pH}$ and heat treatment.

The titratable acidity (\% citric acid) of all the tomato drink treatments remained almost constant $(\mathrm{P}>0.05)$ during the storage with treatment $\mathrm{T}_{1}$ having the highest $(\mathrm{P} \leq 0.05)$ value and treatment $\mathrm{T}_{3}$ the lowest $(\mathrm{P} \leq 0.05)$ value (figure 2 ). During tree tomato drink production, there should be enzymes' denaturation and microorganisms' destruction due to heat treatment (boiling, pasteurisation and sterilisation). Also, the low $\mathrm{pH}$ values of tree tomato drinks are not favourable to microorganisms' activity. Thus, the result obtained is similar to that of El-Dengawy et al. [23] who worked on tomato juice and might be as result of low or neglected metabolic activity. However, the decreasing of titratable acidity (TA) of tomato gradually observed during storage by Abiso et al. [28] and Tilahun et al. [25] could be related to the metabolic activity. In fact, reduction in acidity during storage might be associated to the conversion of organic acids into sugars and their derivatives [32].

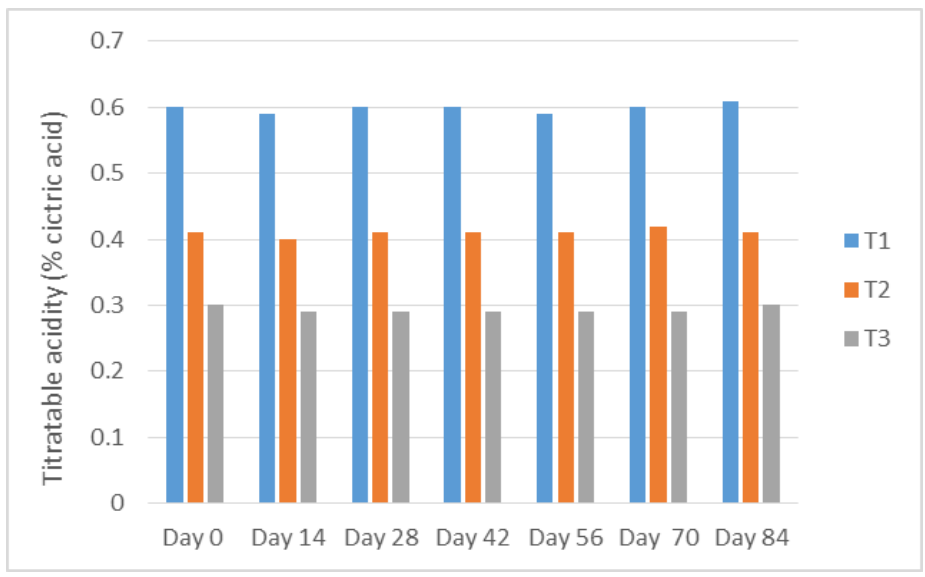

$$
\begin{aligned}
& \mathrm{T}_{1}: 1 \mathrm{~kg} \text { of tree tomato puree and } 11 \\
& \text { of water (dilution } 1: 1 \text { (WW)) } \\
& \mathrm{T}_{2}: 1 \mathrm{~kg} \text { of tree tomato puree and } 21 \\
& \text { of water (dilution } 1: 2(\mathrm{WW}) \text { ) } \\
& \mathrm{T}_{3}: 1 \mathrm{~kg} \text { of tree tomato puree and } 31 \\
& \text { of water (dilution } 1: 3(\mathrm{WW}) \text { ) }
\end{aligned}
$$

Figure 2 Histogram of titratable acidity (\% citric acid) change of tree tomato drink during 84 days (12 weeks) of storage 
The figure 3 reveals that the sugar content remained almost stable during12 weeks of storage. Moreover, treatment $\mathrm{T}_{1}$ persisted to present significantly $(\mathrm{P} \leq 0.05)$ the highest sugar content while treatments $\mathrm{T}_{2}$ and $\mathrm{T}_{3}$ were similar $(\mathrm{P}>0.05)$. The result observed indicates almost no sugar metabolism during storage which might be as the consequence of enzymes' denaturation during boiling, pasteurisation or sterilisation (heat treatments) and also absence or low microbial activity resulting of the heat treatments and the low $\mathrm{pH}$ (acidic $\mathrm{pH}$ ) of the drink which is not suitable for the growth of several microorganisms [24]. This is in agreement with previous studies which indicated that application of $\mathrm{CaCl}_{2}$ (Calcium chloride) leads to greater stability in the total soluble solids or TSS (amount of sugar and soluble minerals present in fruits and vegetables) change, because calcium intervenes on the inhibition of pectic enzymes and stability of the metabolic rate of fruit [33]. Nevertheless, studies done by Márquez et al. [34] revealed that the total soluble solids of tamarillo (tree tomato) tends to increase at the beginning of storage and, it was justified by the hydrolysis of starches, which are broken down into simpler disaccharides and monosaccharides as sucrose, fructose and glucose [35].

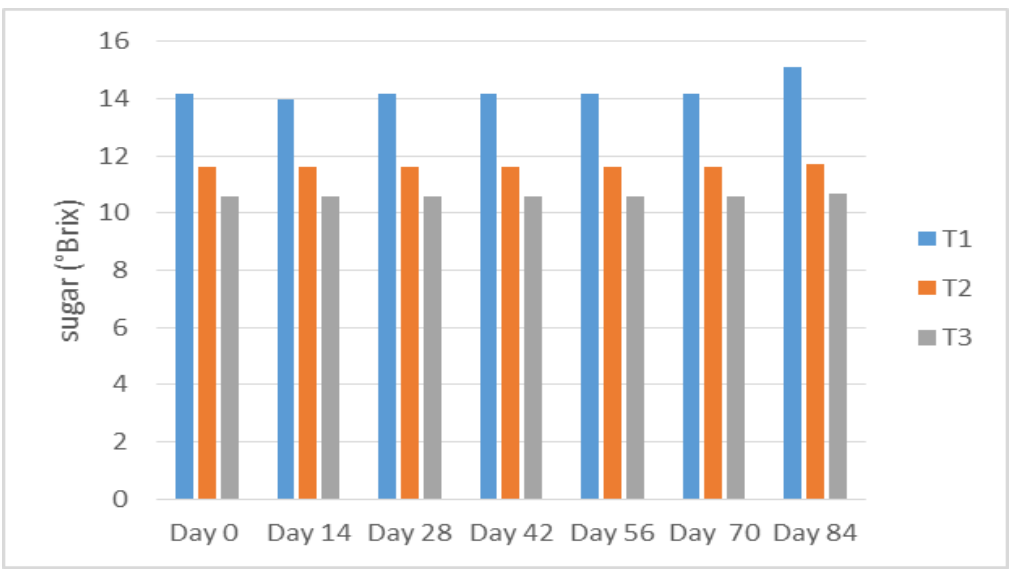

$$
\begin{aligned}
& \mathrm{T}_{1}: 1 \mathrm{~kg} \text { of tree tom ato puree and } 11 \\
& \text { of water (dilution } 1: 1 \text { (WW)) } \\
& \mathrm{T}_{2}: 1 \mathrm{~kg} \text { of tree tom ato puree and } 21 \\
& \text { of water (dilution } 1: 2 \text { (WN)) } \\
& \mathrm{T}_{3}: 1 \mathrm{~kg} \text { of tree tom ato puree and } 31 \\
& \text { of water (dilution } 1: 3 \text { (WW)) }
\end{aligned}
$$

Figure 3 Histogram of sugar ( ${ }^{\circ}$ Brix) change of tree tomato drink during 84 days (12 weeks) of storage

\subsection{Sensory evaluation}

Sensory evaluation scores of different tree tomato drink treatments are presented in table 3 below. The colour of treatment $\mathrm{T}_{3}$ was less appreciated showing that, at high level of dilution, there is loss of the natural colour (dominantly purple) of the tree tomato drink. Concerning the odour, treatment $\mathrm{T}_{2}$ had the best score $(\mathrm{P} \leq 0.05)$ while treatments $\mathrm{T}_{1}$ and $\mathrm{T}_{3}$ were comparable ( $\left.\mathrm{P}>0.05\right)$. This result may be due to the strongest (treatment $\mathrm{T}_{1}$ ) and the lowest (treatment $\mathrm{T}_{3}$ ) odour of the tree tomato when lowly and highly diluted respectively which were not too appreciated by panellists. The taste of treatment $\mathrm{T}_{1}$ was significantly $(\mathrm{P} \leq 0.05)$ less appreciated and it might be due to the high level of acidity of the drink at low level of dilution. The consistency of treatment $\mathrm{T}_{2}$ obtained significantly $(\mathrm{P} \leq 0.05)$ the highest score and treatment $\underline{\mathrm{T}}_{3}$ significantly $(\mathrm{P} \leq 0.05)$ the lowest. It can be justified by the lightness of the drink at high level of dilution or the thickness at low level. The treatment $\mathrm{T}_{2}$ indicated significantly $(\mathrm{P} \leq 0.05)$ the highest score of overall acceptability while other treatments were comparable $(\mathrm{P}>0.05)$. Also, for all the sensory attributes evaluated, treatment $\mathrm{T}_{2}$ presented the highest score. Thus, according to the panellists, the tree tomato drink was better accepted when there was slightly low colour, acidic taste and thick consistency with no strong odour of the tree tomato in the drink.

Table 3 Sensory evaluation scores of fresh tree tomato drink

\section{Treatments}

\begin{tabular}{llll}
\hline Sensory attributes & $\mathbf{T}_{\mathbf{1}}$ & $\mathbf{T}_{\mathbf{2}}$ & $\mathbf{T}_{\mathbf{3}}$ \\
\hline Colour & $3.85 \pm 0.89 \mathrm{a}$ & $3.9 \pm 0.78 \mathrm{a}$ & $2.90 \pm 0.93 \mathrm{~b}$ \\
Odour & $3.45 \pm 0.81 \mathrm{~b}$ & $3.72 \pm 0.90 \mathrm{a}$ & $3.20 \pm 0.91 \mathrm{~b}$ \\
Taste & $3.32 \pm 0.85 \mathrm{~b}$ & $3.90 \pm 0.81 \mathrm{a}$ & $3.25 \pm 0.98 \mathrm{a}$ \\
Consistency & $3.40 \pm 0.77 \mathrm{~b}$ & $3.82 \pm 0.84 \mathrm{a}$ & $3.02 \pm 0.76 \mathrm{c}$ \\
Overall acceptability & $3.37 \pm 0.80 \mathrm{~b}$ & $3.85 \pm 0.80 \mathrm{a}$ & $3.17 \pm 0.98 \mathrm{~b}$
\end{tabular}

$(\mathrm{a}, \mathrm{b}, \mathrm{c})$ : The values with the same letter in the same row are not significant different $(\mathrm{P}>0.05)$; $\mathrm{T}_{1}: 1 \mathrm{~kg}$ of tree tomato puree and $1 \mathrm{l}$ of water $(\mathrm{dilution}$ $1: 1(\mathrm{w} / \mathrm{v})$ ); $\mathrm{T}_{2}: 1 \mathrm{~kg}$ of tree tomato puree and $2 \mathrm{l}$ of water (dilution $1: 2(\mathrm{w} / \mathrm{v})$ ); $\mathrm{T}_{3}: 1 \mathrm{~kg}$ of tree tomato puree and $3 \mathrm{l}$ of water (dilution $1: 3(\mathrm{w} / \mathrm{v})$ ). 
After 12 weeks' storage, the colour, odour and taste of the tree tomato drink samples (treatments) were not significantly different $(\mathrm{P}>0.05)$ according to the panellists (table 4). However, the scores of the consistency and the overall acceptability were highest with treatment $\mathrm{T}_{2}$ and the values observed significantly different $(\mathrm{P} \leq 0.05)$ with those of treatment $\mathrm{T}_{1}$.

Table 4 Sensory evaluation scores of tree tomato drink at the end of storage

\begin{tabular}{llll}
\hline & & Treatments & \\
\hline Sensory attributes & $\mathbf{T}_{\mathbf{1}}$ & $\mathbf{T}_{\mathbf{2}}$ & $\mathbf{T}_{\mathbf{3}}$ \\
\hline Colour & $3.66 \pm 0.84 \mathrm{a}$ & $3.56 \pm 0.81 \mathrm{a}$ & $3.5 \pm 0.82 \mathrm{a}$ \\
Odour & $3.46 \pm 0.73 \mathrm{a}$ & $3.4 \pm 0.85 \mathrm{a}$ & $3.16 \pm 1.01 \mathrm{a}$ \\
Taste & $3.13 \pm 0.73 \mathrm{a}$ & $3.56 \pm 0.62 \mathrm{a}$ & $3.33 \pm 1.12 \mathrm{a}$ \\
Consistency & $3.03 \pm 0.92 \mathrm{~b}$ & $3.56 \pm 0.77 \mathrm{a}$ & $3.33 \pm 0.84 \mathrm{ab}$ \\
Overall acceptability & $2.90 \pm 0.75 \mathrm{~b}$ & $3.48 \pm 0.63 \mathrm{a}$ & $3.30 \pm 0.98 \mathrm{ab}$ \\
\hline
\end{tabular}

$(\mathrm{a}, \mathrm{b}, \mathrm{c})$ : The values with the same letter in the same rows are not significant different $(\mathrm{P}>0.05) \mathrm{T}_{1}: 1 \mathrm{~kg}$ of tree tomato puree and $1 \mathrm{l}$ of water $(\mathrm{dilution}$ $1: 1(\mathrm{w} / \mathrm{v})) ; \mathrm{T}_{2}: 1 \mathrm{~kg}$ of tree tomato puree and $1 \mathrm{l}$ of water (dilution 1:2(w/v)); $\mathrm{T}_{3}: 1 \mathrm{~kg}$ of tree tomato puree and $1 \mathrm{l}$ of water (dilution 1:3 (w/v)).

\section{Conclusion}

The tree tomato drink treatment present the highest titratable acidity, dry matter content, sugar content and ash content when low diluted (treatment $\mathrm{T}_{1}$ ) and also, its $\mathrm{pH}$ increases with dilution. Titratable acidity, sugar content and $\mathrm{pH}$ of the tree tomato drink is not affected after 12 weeks' storage. At 1:2 (w/v) dilution (treatment $\mathrm{T}_{2}$ ), the tree tomato is more preferable concerning the odour, consistency and overall acceptability while at 1:1 (w/v) dilution (treatment $\mathrm{T}_{1}$ ), the taste is less appreciated. The increase of the dilution leads to a decrease of appreciation of the colour. After 12 weeks' storage all the treatment presents the same level of appreciation in term of colour, odour and taste. However, the consistency and the overall acceptability of treatment $\mathrm{T}_{2}$ are more accepted than that the ones of treatment $\mathrm{T}_{1}$.

\section{Compliance with ethical standards}

\section{Acknowledgments}

The authors thank the staff of IRAD Bambui and especially that of Food Technology and Post-Harvest Laboratory as well as the students of College of Technology from the University of Bamenda on internship at IRAD Bambui for their assistance and support during the experimental and analytical work. Also, the authors thanks Dr Lendzemo Wirnkar Venasius for his support during the progress of the work.

\section{Disclosure of conflict of interest}

There is no conflict of interest

\section{References}

[1] Sánchez-Vega I. (1992). Frutales Andinos. In: Hernández-Bermejo JE, León J (eds). Cultivos marginados, otra perspectiva de 1492. Col FAO: Prod Prot Veg 26. FAO, Rome, Italy, 179-189.

[2] Heatherbel DA, Surawski JR and Withy LM. (1975). Identification and quantitative analysis of sugar and nonvolatile acids in tamarillo (Cyphomandra betacea). Confructa, 20, 17-22.

[3] Bohs L. (1991). Crossing studies in Cyphomandra (Solanaceae) and their systematic and evolutionary significance. American Journal of Botany, 78, 1683-1693.

[4] Bohs L and Nelson A. (1997). Solanum maternum (Solanaceae), a new Bolivian relative of the tree tomato. Novon, 7, 341-345.

[5] Bohs L. (1994). Cyphomandra (Solanaceae). Flora Neotropica Monogr 63. The New York Botanical Garden, New York, USA, 175. 
[6] Bohs L. (1995). Transfer of Cyphomandra (Solanaceae) and its species to Solanum. Taxon, 44, 583-587.

[7] Lester RN and Hawkes JG. (2001). Solanaceae. In: Hanelt P, Institute of Plant Genetics and Crop Research (eds). Mansfeld's encyclopedia of agricultural and horticultural crops (except ornamentals). Springer, Berlin, Germany. 4, 1790-1856.

[8] Espinal CF, Martínez HJ and Peña Y. (2005). La cadena de los frutales de exportación en Colombia: Una mirada global de su estructura y dinámica 1991-2005. Documento de Trabajo No. 67. Ministerio de Agricultura y Desarrollo Rural, Bogotá, Colombia, 66.

[9] Acosta-Quezada PG, Martinez-Laborde JB and Prohens J. (2011). Variation among tree tomato (Solanum betaceum Cav.) accessions from different cultivar groups: implications for conservation of genetic resources and breeding. Genetic Ressources and Crop Evolution, 58, 943-960.

[10] Scotsmans WC, East A and Woolf A. (2011). Tamarillo. In: Yahia EM (ed.) Postharvest biology and technology of tropical and subtropical fruits, Volume 4. Woodhead Publishing, Sawston, Cambridge, UK, 427-441.

[11] Pone KD, Imele H and SIBADEF. (2009). Report: 'Studies of Cameroon Traditional Foodstuffs in the North West Region.

[12] Prohens J and Nuez F. (2000). The tamarillo (Cyphomandra betacea): a review of a promising small crop. Small Fruits Review, 1(2), 43-68.

[13] Wills RBH, Lim JSK and Greenfield H. (1986). Composition of Australian foods: 31 Tropical and subtropical fruit. Food Technology Association of Australia, 38, 118-123.

[14] Popenoe H, King S, Leon J, Kalinowski L, Vietmeyer N, Dafforn M and Mortino M. (1989). Lost Crops of the Incas: Little-known Plant of the Andes with Promise for Worldwide Cultivation. National Academy Press, Washington, DC, USA, 306-316.

[15] Romero-Rodriguez MA, Vazquez-Oderiz ML, Lopez-Hernandez J and Simal-Lozano J. (1994). Composition of babaco, feijoa, passionfruit and tamarillo produced in Galicia (north-west Spain). Food Chemistry, 49, 23-27.

[16] Vera de Rosso V and Mercadante AZ. (2007). HPLC-PDA-MS/MS of anthocyanins and carotenoids from dovyalis and tamarillo fruits. Journal of Agricultural and Food Chemistry, 55, 9135-9141.

[17] Orwa C, Mutua A, Kindt R, Jamnadass R and Anthony S. (2009). Agroforestree database: a tree reference and selection guide version 4.0. Word Agroforestry Centre, Kenya, 6.

[18] Tene V, Malangon O, Vita Finzi P, Vidari G, Armijos CH and Zaragoza T. (2007). An ethnobotanical survey of medicinal plants used in Loja and Zamora-Chinchipe Ecuador. Jounal of Ethnopharmacology, 111, 63-81.

[19] Schmeda-Hirschmann G, Feresin G, Tapia A, Hilgert N and Theoduloz C. (2005). Proximate composition and free radical scavenging activity of edible fruits from the Argentinian yungas. Journal of the Science of Food and Agriculture, 85, 1357-1364.

[20] Palash M and Mitali G. (2012). Antioxidant activities of different parts of tree tomato fruit. International Journal of Pharmaceutical Sciences Review and Research, 13(2), 39-47.

[21] Kong JM, Chia LS, Goh NK, Chia TF and Brouillard R. (2003). Analysis and biological activities of anthocyanins. Phytochemistry, 64(5), 923-933.

[22] AOAC. (1990). Official methods of analysis. 15th ed Washington DC. Edr. Washington DC.

[23] El-Dengawy RAH, El-said SMM, El-Kadi SM and Shalata AAM (2016). Effect the Industrial Process and the Storage Periods on the Nutritional Value of Tomato Juice. Indian Journal of Nutrition, 3(1), 1-4.

[24] Park SH, Lamsal BP and Balasubramaniam VM. (2014). Principles of Food Processing. In Stephanie Clark, Stephanie Jung, and Buddhi Lamsal (Eds), Food Processing: Principles and Applications, Second Edition. John Wiley \& Sons, Ltd.

[25] Tilahun S, Park DS, Taye AM and Jeong CS. (2017). Effects of Storage Duration on Physicochemical and Antioxidant Properties of Tomato (Lycopersicon esculentum Mill.). Horticultural Science and Technology, 35(1), 88-97.

[26] Moneruzzaman KM, Hossain ABMS, Sani W, Saifuddin M and Alinazi M. (2009). Effect of harvesting and storage conditions on the postharvest quality of tomato (Lycopersicon esculentum Mill) cv. Roma VF. Australian Journal of Crop Science, 3(2), 113-121. 
[27] Islam M., Morimoto T and Hatou K. (2012). Storage behavior of tomato inside a zero energy cool chamber. Agricultural Engineering International CIGR Journal, 14(4), 209-217.

[28] Abiso E, Satheesh N and Hailu A. (2015). Effect of storage methods and ripening stages on postharvest quality of tomato (Lycopersicom esculentum Mill) CV. Chali. Annals, Food Science and Technology, 16(1), 127-137.

[29] Albertini MV, Carcouet E, Pailly O, Gambotti C, Luro F and Berti L. (2006). Changes in organic acids and sugars during early stages of development of acidic and acidless citrus fruit. Journal of Agricultural and Food Chemistry, $54,8335-8339$.

[30] Pinzón-Gómez LP, Deaquiz YA and Álvarez-Herrera JG. (2014). Postharvest behavior of tamarillo (Solanum betaceum Cav.) treated with $\mathrm{CaCl} 2$ under different storage temperatures. Agronomía Colombiana, 32(2), 238245.

[31] Ernani P, Dias J, Vidal C, Cardoso D and Rogeri DA. (2008). Preharvest calcium sprays were not always needed to improve quality of 'Gala' apples in Brazil. Revista Brasileira de Fruticultura, 30, 892-896.

[32] Rai GK, Kumar R, Singh AK, Rai PK, Rai M, Chaturvedi AK and Rai AB. (2012). Changes in antioxidant and phytochemical properties of tomato (Lycopersicon esculentum mill.) under ambient condition. Pakistan Journal of Botany, 44(2), 667-670.

[33] García A and Praderas G. (2010). Influencia del Cloruro de Calcio y de un tipo de empaque sobre las propiedades fisicoquímicas y la textura de la fresa (Fragaria x ananassa Duch.) durante el almacenamiento. Revista Facultad Nacional de Agronomia Medellin, 63, 5417-5427.

[34] Márquez J, Otero M and Cortes M. (2007). Cambios fisiológicos, texturales, fisicoquímicos y microestructurales del tomate de árbol (Cyphomandra betacea S.) en poscosecha. Vitae, 13, 9-16.

[35] Kan I. (2008). Yield quality and irrigation with saline water under environmental limitations: the case of processing tomatoes in California. Agricultural Economics, 38, 57-66.

\section{How to cite this article}

Njoya MA, Nain CW, Nde SC, Mahbou PY and Imele H. (2020). Physicochemical and sensory properties of tree tomato (Cyphomandra betacea (Cav.) Sendtner) drink. World Journal of Advanced Research and Reviews, 6(2), 09-16. 